\title{
Intraoperative assessment of biliary anatomy for prevention of bile duct injury: a review of current and future patient safety interventions
}

\author{
K. Tim Buddingh • Vincent B. Nieuwenhuijs • \\ Lianne van Buuren · Jan B. F. Hulscher • \\ Johannes S. de Jong • Gooitzen M. van Dam
}

Received: 23 July 2010/Accepted: 28 January 2011/Published online: 13 April 2011

(c) The Author(s) 2011. This article is published with open access at Springerlink.com

\begin{abstract}
Background Bile duct injury (BDI) is a dreaded complication of cholecystectomy, often caused by misinterpretation of biliary anatomy. To prevent BDI, techniques have been developed for intraoperative assessment of bile duct anatomy. This article reviews the evidence for the different techniques and discusses their strengths and weaknesses in terms of efficacy, ease, and cost-effectiveness.

Method PubMed was searched from January 1980 through December 2009 for articles concerning bile duct visualization techniques for prevention of BDI during laparoscopic cholecystectomy.

Results Nine techniques were identified. The critical-viewof-safety approach, indirectly establishing biliary anatomy, is accepted by most guidelines and commentaries as the surgical technique of choice to minimize BDI risk. Intraoperative cholangiography is associated with lower BDI risk (OR 0.67, CI 0.61-0.75). However, it incurs extra costs, prolongs the operative procedure, and may be experienced as cumbersome. An established reliable alternative is laparoscopic ultrasound, but its longer learning curve limits widespread implementation. Easier to perform are cholecystocholangiography and dye cholangiography, but these
\end{abstract}

K. T. Buddingh · V. B. Nieuwenhuijs · L. van Buuren ·

J. B. F. Hulscher · J. S. de Jong

Department of Surgery, University Medical Center Groningen,

Groningen, the Netherlands

e-mail: k.t.buddingh@chir.umcg.nl

G. M. van Dam $(\varangle)$

Department of Surgery, BioOptical Imaging Center Groningen, University Medical Center Groningen, Post Box 30.001,

9700 RB Groningen, the Netherlands

e-mail: g.m.van.dam@chir.umcg.nl yield poor-quality images. Light cholangiography, requiring retrograde insertion of an optical fiber into the common bile duct, is too unwieldy for routine use. Experimental techniques are passive infrared cholangiography, hyperspectral cholangiography, and near-infrared fluorescence cholangiography. The latter two are performed noninvasively and provide real-time images. Quantitative data in patients are necessary to further evaluate these techniques.

Conclusions The critical-view-of-safety approach should be used during laparoscopic cholecystectomy. Intraoperative cholangiography or laparoscopic ultrasound is recommended to be performed routinely. Hyperspectral cholangiography and near-infrared fluorescence cholangiography are promising novel techniques to prevent BDI and thus increase patient safety.

Keywords Cholecystectomy - CBD - Common bile duct . Complications

\author{
Abbreviations \\ BDI Bile duct injury \\ LC Laparoscopic cholecystectomy \\ CBD Common bile duct \\ CVS Critical view of safety \\ IOC Intraoperative cholangiography \\ CCC Cholecystocholangiography \\ LUS Laparoscopic ultrasound \\ NIRF-C Near-infrared fluorescence cholangiography
}

Cholecystectomy is one of the most frequently performed operations in the Western world, with over 750,000 yearly in the United States alone [1]. Bile duct injury (BDI) is a dreaded complication of cholecystectomy. When the 
laparoscopic technique was introduced in the early 1990s an increase of BDI was noted from approximately $0.2 \%$ to about $0.5 \%$ [2].

The burden of BDI on patients is considerable. Reinterventions through surgical, endoscopic, or radiologic procedures in specialist centers are frequently necessary [3-5]. BDI has low but finite short- and long-term mortality rates $[6,7]$. A recent study reported that $\mathrm{BDI}$ had a significant negative effect on quality of life even 10 years after the event [8]. BDI is also associated with substantial financial burden for the health-care system: A British study calculated an average cost of 108,000£ ( 175,000 \$US) for major BDI (hospital and society costs). In addition, BDI is frequently grounds for malpractice litigation $[7,9,10]$.

During laparoscopic cholecystectomy the primary cause of BDI is an error of visual perception (in $71-97 \%$ of cases), not insufficient technical skill of the surgeon $[11,12]$. Factors that impede visual assessment and increase the risk of BDI include past or ongoing inflammation, variant ductal anatomy, and limited surgical experience [2,13].

To prevent BDI, systematic safety interventions have been developed to provide insight into the biliary anatomy during cholecystectomy. For such an intervention to be effective, it first needs to be safe for patients and personnel. Second, it needs to be simple to use and easy to interpret since a wide range of surgeons and residents perform cholecystectomies. Third, considering the large volume of cholecystectomies and the continuous pressure to keep health-care expenditures under control, extra operating time, material expenses, and personnel expenses need to be kept to a minimum.

This review aims to provide an overview of the different modalities for intraoperative assessment of biliary anatomy during cholecystectomy and discuss their strengths and weaknesses.

\section{Methods}

The electronic database PubMed and the Web of Science were searched from January 1980 through November 2010 for English language articles concerning techniques of intraoperative assessment of biliary anatomy for prevention of BDI. The following search terms were used: "bile duct injury," "cholecystectomy," "intraoperative cholangiography," "cholangiography," "bile duct visualization," "bile duct imaging," and "bile duct mapping." The reference lists of the selected articles were also searched.

To portray the protective effect of conventional intraoperative cholangiography (IOC) on BDI in a forest plot, all studies of more than 10,000 patients were selected that explicitly compared the incidence of BDI in (laparoscopic) cholecystectomy with IOC to that without IOC. Studies that compared only the routine use of IOC with selective use were not included in the forest plot.

Microsoft Office Excel 2003 (Microsoft, Redmond, WA, USA) and SPSS v16.0 for Windows (SPSS Inc., Chicago, IL, USA) were used for the statistical analysis and to create the forest plot.

\section{Results}

The identified studies on the different imaging modalities are portrayed in Table 1 .

Critical view of safety (CVS)

Although CVS is not an imaging modality per se, the operative technique plays a major role in establishing the anatomical orientation of the bile ducts and therefore needs to be discussed in this review.

Already in 1995, Strasberg et al. [14] described the "critical view of safety" (CVS) approach. Calot's triangle is dissected to achieve the following: First, one third of the gallbladder must be dissected free from the liver bed. Second, the triangle of Calot must be cleared (with liver segment $\mathrm{V}$ visible through the window). Third, the cystic artery and cystic duct must be the only two tubular structures remaining between the gallbladder and the hepatoduodenal ligament. In some cases, the cystic artery is diathermically dissected close to the gallbladder, in which case only the cystic duct remains to form the CVS. It is not necessary or recommended that the CBD be visualized. In this manner, the bile duct remaining can be none other than the cystic duct.

Achievement of the CVS is recorded in the operation report, preferably augmented by laparoscopic video or photographic images [15]. Failure to achieve the CVS is an absolute indication for conversion or additional bile duct imaging.

Four series, totaling close to 4,500 patients, have been published in which cholecystectomies have explicitly been performed using the CVS technique [16-19]. All four series showed very low BDI rates $(0-0.03 \%)$. A Japanese review article noted a decrease in self-reported BDI during laparoscopic cholecystectomy from $0.77 \%$ in 2005 to $0.58 \%$ in 2007 and suggested that the increased implementation of the CVS technique played a role in this decrease [20]. Strasberg [21] mentioned the lack of level 1 evidence that the CVS approach prevents bile duct injury in his recent commentary.

Although undoubtedly a great step toward safer cholecystectomy, it is unclear whether the CVS alone is sufficient as a technique to minimize the risk of BDI. Our own 
Table 1 Evidence on the different modalities for intraoperative assessment of the biliary tree

\begin{tabular}{llll}
\hline Primary author & $\begin{array}{l}\text { No. of } \\
\text { patients }\end{array}$ & Study description & Outcome \\
\hline
\end{tabular}

CVS-patient series of LCs using the CVS

$\begin{array}{lll}\begin{array}{l}\text { Rawlings [19] } \\ \text { Sanjay [18] }\end{array} & 447 & \begin{array}{c}\text { All patients (suffering from biliary colic) underwent single-port } \\ \text { LC using the CVS technique. } \\ \text { All patients (acute pathology) underwent LC using the CVS } \\ \text { technique. }\end{array} \\ \text { Avgerinos [16] } & 1,046 \quad \begin{array}{l}\text { All patients underwent LC using the CVS technique. } \\ \text { Yegiyants [17] }\end{array} 3,046 \quad \begin{array}{c}\text { Administrative data of an institution in which CVS was standard. } \\ \text { Injuries requiring surgical repair were identified. }\end{array}\end{array}$

IOC-studies $>10,000$ patients on the association between IOC and BDI
Z'graggen [34] 10,174 1992-1995; analysis of LCs in a prospective database for which numerous Swiss institutions provide data (SALTS).

CVS in all patients;

0 BDI, 0 bile leaks

CVS achieved in $388(87 \%)$;

0 BDI, 0 bile leaks

CVS achieved in 998 (95\%);

0 BDI, 5 bile leaks $(0.5 \%)$

CVS percentage not assessed;

1 BDI $(0.03 \%)$, bile leaks not assessed

OR for BDI using IOC $=0.97(95 \% \mathrm{CI}$

0.44-2.18), unadjusted for confounders

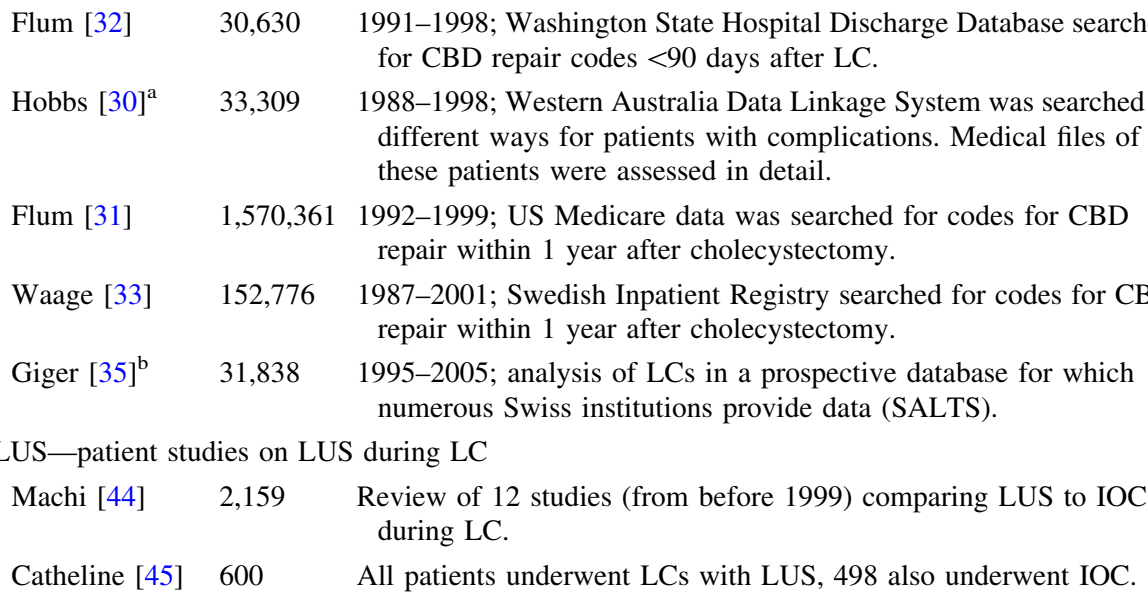

\begin{tabular}{|c|c|c|c|}
\hline Kimura [49] & 183 & All patients underwent LCs with LUS and IOC. & $\begin{array}{l}\text { LUS success } 95 \% \text {; IOC success } 96 \% \text {; } 0 \\
\text { BDI; } 1 \text { bile leak after choledochotomy }\end{array}$ \\
\hline Tranter [54] & 367 & All patients underwent LC with LUS. & LUS success $99 \%$; BDI not reported \\
\hline Biffl $[46]$ & 844 & $\begin{array}{l}\text { Nonrandomized comparison between LC with LUS }(n=248) \text { and } \\
\text { without LUS (594). }\end{array}$ & $\begin{array}{l}\text { Without LUS: } 11 \text { BDI }(1.9 \%) \text {; routine } \\
\text { LUS: } 0 \text { BDI }(P=0.04)\end{array}$ \\
\hline Catheline [47] & 900 & All patients underwent LCs with LUS and IOC. & $\begin{array}{l}\text { LUS success } 100 \% \text {; IOC success } 85 \% \text {; } \\
\text { BDI not reported }\end{array}$ \\
\hline Tranter [55] & 135 & All patients underwent LCs with LUS and IOC. & $\begin{array}{l}\text { LUS success } 97 \% \text {, IOC success } 90 \% \text {; BDI } \\
\text { not reported }\end{array}$ \\
\hline Onders [52] & 256 & Description of one surgeon's experience with LUS. & $\begin{array}{l}\text { Increase in use of LUS from } 29 \% \text { in } 2001 \\
\text { to } 77 \% \text { in } 2004 ; 0 \text { BDI }\end{array}$ \\
\hline Machi [50] & 200 & All patients underwent LC with LUS. & LUS success in $97 \%$; 0 BDI, 0 bile leaks \\
\hline Perry [53] & 236 & All patients underwent LC with LUS. & LUS success in $95 \% ; 0$ BDI; 0 bile leaks \\
\hline Hakamada [48] & 644 & $\begin{array}{l}\text { Comparison of outcome before }(n=368) \text { and after }(n=276) \\
\text { introduction of routine LUS. }\end{array}$ & $\begin{array}{l}\text { Without LUS: } 4 \text { BDI }(1.1 \%) \text {; routine LUS: } \\
0 \text { BDI }(P=0.08)\end{array}$ \\
\hline Machi [51] & 1,381 & Prospective multicenter series of LC with LUS. & LUS success $98 \%$; 0 BDI; 3 leaks $(0.2 \%)$ \\
\hline \multicolumn{4}{|c|}{$\mathrm{CC}$ - patient studies on CCC during LC } \\
\hline Wills [58] & 76 & $\begin{array}{l}\text { Randomized controlled trial between IOC }(n=36) \text { and CCC } \\
(n=40) \text { during LC. }\end{array}$ & $\begin{array}{l}\text { IOC success in } 100 \%, \text { CCC in } 72 \% \\
\quad(P<0.001) ; \text { CCC images of poor quality }\end{array}$ \\
\hline Daoud [59] & 325 & $\begin{array}{l}\text { Nonrandomized comparison between IOC }(n=35) \text { and CCC } \\
(n=290) \text {. }\end{array}$ & IOC success $83 \%$, CCC success $86 \%$ \\
\hline Glattli [60] & 69 & $\begin{array}{l}\text { Nonrandomized comparison between IOC }(n=38) \text { and CCC } \\
\quad(n=31) \text {. }\end{array}$ & $\begin{array}{l}\text { IOC success } 92 \% \text {, CCC success } 48 \% \text {; CCC } \\
\text { images of inferior quality }\end{array}$ \\
\hline
\end{tabular}

Success of LUS and IOC $88-100 \%$; BDI not assessed

LUS and IOC equal success; LUS faster (10 vs. $18 \mathrm{~min}, P=0.001)$ BDI not reported

OR for BDI using IOC $=0.58(95 \% \mathrm{CI}$ 0.44-0.72), adjusted for confounders

OR for BDI using IOC $=1.14(95 \% \mathrm{CI}$

0.76-1.70), unadjusted for confounders
OR for BDI using $\mathrm{IOC}=0.75(95 \% \mathrm{CI}$
$0.59-0.92)$, adjusted for confounders

OR for BDI using IOC $=0.68(95 \% \mathrm{CI}$

$0.42-1.03$ ), adjusted for confounders

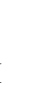


Table 1 continued

\begin{tabular}{|c|c|c|c|}
\hline Primary author & $\begin{array}{l}\text { No. of } \\
\text { patients }\end{array}$ & Study description & Outcome \\
\hline Fox $[61]$ & 113 & All patients underwent LC with CCC. & CCC was successful in $81 \%$ \\
\hline Koksal [62] & 40 & All patients underwent $\mathrm{LC}$ with $\mathrm{CCC}$. & CCC was successful in $90 \%$ \\
\hline Moont [63] & 97 & All patients underwent $\mathrm{LC}$ with $\mathrm{CCC}$. & CCC was successful in $85 \%$ \\
\hline Young [64] & 194 & All patients underwent $\mathrm{LC}$ with $\mathrm{CCC}$. & CCC was successful in $81 \%$ \\
\hline Holzman [65] & 60 & Patients underwent "partial CCC" with the Kumar clamp. & Kumar CCC was successful in $83 \%$ \\
\hline Kumar [66] & 50 & Patients underwent "partial CCC" with the Kumar clamp. & Kumar CCC was successful in $98 \%$ \\
\hline \multicolumn{4}{|c|}{ Dye cholangiography—patient series on dye cholangiography during LC } \\
\hline $\begin{array}{l}\text { Pertsemlidis } \\
\text { [67] }\end{array}$ & 18 & $\begin{array}{l}\text { Indocyanine green (ICG) was intravenously administered to patients } \\
\text { undergoing LC. }\end{array}$ & $\begin{array}{l}\text { Cystic duct and CBD colored green in all } \\
\text { patients. No images provided }\end{array}$ \\
\hline Sari [68] & 46 & Blue dye was injected into the gallbladder during LC. & $\begin{array}{l}\text { Cystic duct and CBD colored blue in } \\
43 / 46 \text { patients }\end{array}$ \\
\hline $\mathrm{Xu}[69]$ & 20 & Blue dye was injected into the gallbladder during LC. & $\begin{array}{l}\text { Extrahepatic bile ducts colored blue in } \\
18 / 20 \text { patients. No images provided }\end{array}$ \\
\hline
\end{tabular}

Light cholangiography-patient series

$\begin{array}{ccc}\mathrm{Xu} \text { [69] } & 16 \mathrm{O} \text { Optical fiber led into the CBD with a duodenoscope during LC. CBD CBD visualized in } 13 \text { cases, cystic duct } \\ \text { cannulation successful in 13/16 patients. } & \text { only in } 4 \text { cases. No images provided }\end{array}$

Passive infrared cholangiography—animal study

Liu [70] 6 pigs $\quad$ Room temperature saline was infused into the biliary tract. Images were taken with an infrared camera.

Near-infrared cholangiography (NIRF-C) — patient studies on NIRF-C Mitsuhashi [73] $5 \quad \begin{aligned} & \text { Open cholecystectomy after intravenous infusion of ICG. A NIRF } \\ & \text { camera system was used to capture images. }\end{aligned}$

Ishizawa [71] $1 \quad$ First laparoscopic experience with NIRF-C during cholecystectomy.

Ishizawa [74] $10 \quad$ Open cholecystectomy after intravenous infusion of ICG. A NIRF camera system was used to capture images.

Aoki [75] $\quad 14 \quad$ LC after intravenous administration of ICG.

Tagaya [76] $12 \quad$ LC after intravenous ICG. Hepatoduodenal ligament was compressed with plastic device for improved exposure.

Ishizawa [86] $52 \quad$ LC after intravenous ICG.
Infrared images correlated well with IOC. Artificial stones and BDI detected

Fluorescence observed in the liver, gallbladder, and bile ducts of all patients

Fluorescence observed in cystic duct and CBD

Cystic duct and CBD were identified in 9/10 patients using NIRF-C

CBD-cystic duct junction identified in 10/14 patients

The CBD-cystic duct junction was identified in all patients

CBD-cystic duct junction identified in 50/52 patients

Hyperspectral cholangiography_animal studies

Zuzak [82] $\quad 1$ pig A laparoscopic near-infrared, hyperspectral imaging system was used to assess bile duct anatomy in a pig.

Bile ducts, arteries, and veins all have unique reflectance spectra

Livingston [81] 8 pigs Characteristics of different types of tissue were assessed using a laparoscopic hyperspectral imaging system.
Bile ducts, arteries, and veins all have unique reflectance spectra

$L C$ laparoscopic cholecystectomy, $C V S$ critical view of safety, $B D I$ bile duct injury, $I O C$ intraoperative cholangiography, $L U S$ laparoscopic ultrasound, $C C C$ cholecystocholangiography, $N I R F-C$ near-infrared fluorescence cholangiography, $C B D$ common bile duct, $I C G$ indocyanine green, $O R$ odds ratio

${ }^{a}$ Includes data set of Fletcher et al. [84]

b Includes data set of Krahenbuhl et al. [85]

data show occurrence of major BDI even after the CVS approach was adopted (unpublished). Also, major BDI continues to occur in the Netherlands despite increasing adoption of the CVS technique [4].

In spite of the lack of level 1 evidence, virtually all recent reviews, guidelines, and commentaries advocate the CVS technique [22-24]. Without an eligible alternative, the CVS should be regarded as the gold standard among operative techniques for assessment of biliary anatomy during laparoscopic cholecystectomy.

Intraoperative cholangiography (IOC)

Intraoperative cholangiography (IOC) is the most frequently applied technique for intraoperative assessment of the biliary anatomy. After dissection in Calot's triangle, the 
surgeon identifies and cannulates the cystic duct at the junction with the gallbladder. Radiographic contrast is then injected into the cystic duct and (subtracted) X-ray fluoroscopy images are obtained. The advent of dynamic fluoroscopy has improved the speed with which IOC can be performed and yields a series of high-resolution images that more accurately depict the biliary anatomy $[25,26]$. IOC identifies whether the cannulated duct is indeed the cystic duct or mistakenly the CBD. In the latter case, the ductotomy may be repaired by inserting a T-tube and complete transection of the CBD is prevented. IOC may also identify abnormal biliary anatomy such as an accessory cystic duct or an aberrant right hepatic duct. IOC allows early detection of BDI, in which case a blush of contrast originating from the biliary tract or clips placed over the common or hepatic bile ducts may be seen. Quoted success rates are generally around or up to $90 \%$ $[27,28]$.

It has been calculated that a sufficiently powered, randomized controlled trial to assess the impact of IOC on BDI would need to include more than 30,000 patients [29]. As a result, the evidence of the role of IOC in the prevention of BDI consists mainly of population-based studies (Table 1). Figure 1 shows a forest plot of the six largest population-based studies (each $>10,000$ patients) [30-35] that compare the incidence of BDI in cholecystectomies explicitly performed using IOC to that in cholecystectomies explicitly performed without IOC. From this metaanalysis, the OR for BDI when using IOC was 0.67 (range $=0.61-0.75$ ). When the studies were weighted

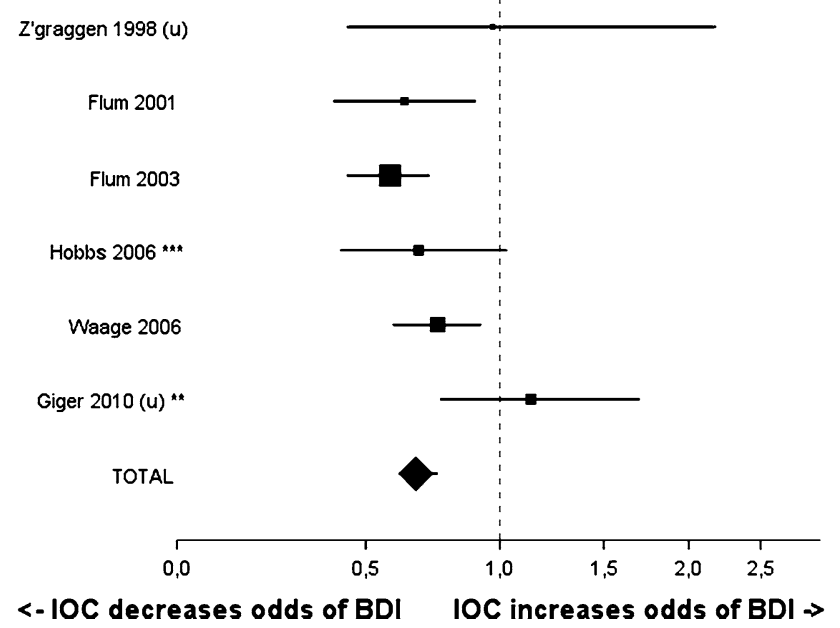

Fig. 1 Forest plot of protective effect of IOC on BDI during cholecystectomy [30-35]. OR odds ratio, BDI bile duct injury, IOC intraoperative cholangiography. *Unadjusted OR; **The data set of Fletcher et al. [84] is included in the study by Hobbs et al. [30]. ***The data set of Krahenbuhl et al. [85] is included in the study by Giger et al. [35]. Studies were weighted by the square root of the study size. Results are plotted on a natural logarithmic scale according to actual size rather than the square root of the size, the OR was 0.60 (range $=0.52-0.70$ ). Although the strongest evidence available, these studies are prone to bias and confounders as they rely heavily on administrative data of heterogeneous groups. For example, in these studies IOCs that were performed only because BDI was already suspected or observed, were included in the "IOC group." For this reason, the number of BDIs that occurred when IOC was used could have been substantially higher than the true incidence.

Perhaps even more relevant than whether IOC in itself is useful is the question of whether it should be performed routinely or selectively. Metcalfe et al. [36] reviewed eight retrospective series of laparoscopic cholecystectomies (total of 6,024 patients) with routine IOC and nine series (3,268 patients) with a selective IOC policy. In this underpowered study, the rates of complete CBD transection were not significantly different, although a larger proportion of BDI was identified intraoperatively when routine IOC was used. Flum et al. [31], in their analysis of 1.5 million patients, found a lower incidence of BDI with surgeons who used IOC routinely: $0.43 \%$ vs. $0.51-0.54 \%$ $(P<0.001)$.

An important limitation of all the mentioned studies is that the cholecystectomies described took place mostly in the 1990s. During this era, the CVS technique was not yet widely implemented and therefore the studies can provide no information on the added value of IOC when the CVS technique is used. In our university hospital we retrospectively evaluated the implementation of a routine IOC policy in a population in which CVS was already the standard of care. We found 8/421 (1.9\%) major BDIs before implementation of routine IOC versus $0 / 435$ cholecystectomies after implementation of routine IOC $(P=0.004)$ (personal data). Although the CVS was the standard of care for all these patients, these data are limited in its retrospective nature.

In an editorial, Talamini [37] rightly pointed out that if the association between IOC and BDI is accepted to be causal, this will "radically alter the current practice of cholecystectomy."

Notwithstanding the association of IOC with lower BDI rates, it has several disadvantages which impede routine implementation. Cystic duct cannulation can be challenging, especially when it involves a short, thin, or brittle cystic duct, and the reported extra time needed for IOC is 10-27 min [38-40]. Special attention should be paid to the learning curve for interpreting IOC, as some studies report high proportions of incorrectly interpreted cholangiograms. For example, Way et al. [11] demonstrated that 34/43 (79\%) routine cholangiograms that showed BDI were incorrectly interpreted. The radiation received during IOC is only around $0.18 \mathrm{mSv}$ and represents a less than $0.001 \%$ 
lifetime added risk of developing cancer [41]. Radiation exposure is therefore no argument against routine use of IOC in the adult population.

Another advantage of IOC is that the learning curve is generally short: a success rate of $95 \%$ was reached in an institution of eight supervising surgeons after 46 procedures [42]. Our own data, too, indicate a short learning curve: a success rate of $90 \%$ was reached in the first 3 months after implementation of routine IOC (personal data).

Whether routine IOC is cost effective depends on the estimated cost of IOC, the reduction of the BDI rate, and the cost to repair a BDI, patient death, and malpractice litigation. Flum et al. [43] entered varying estimates into cost-effectiveness models and concluded that if the relationship between IOC and lower BDI is indeed causal, routine application of IOC is cost effective.

In summary, there is a well-established relationship between IOC and lower incidence and increased early detection of BDI. It should be taken into account that these data are from before the CVS era and might not be extrapolated. Also, the sometimes cumbersome and timeconsuming procedure limits the routine use of IOC in clinical practice.

\section{Laparoscopic ultrasound (LUS)}

An alternative to radiography for intraoperative assessment of biliary anatomy is laparoscopic ultrasonography (LUS). Laparoscopic flexible multifrequency ultrasound transducers with a Doppler flow detection system visualize tissue $4 \mathrm{~cm}$ in length and $6 \mathrm{~cm}$ in depth. The extrahepatic bile ducts may be scanned in the transverse and longitudinal planes. LUS can identify the CBD, the bifurcation cystic duct-CBD, hepatic artery, portal vein, inferior vena cava, and ampulla.

In 1999, Machi et al. [44] reviewed 2,059 patients who underwent both LUS and IOC and found a success rate of over $90 \%$ for both modalities. In the following years, extra evidence has been amassed on the value of LUS [45-55] (Table 1). Virtually all these studies report success rates of more than $95 \%$, comparable to or higher than that of IOC. The intrapancreatic and intrahepatic parts of the biliary system are not always accurately depicted with LUS. The time needed for LUS ranges between 5 and $10 \mathrm{~min}$.

One retrospective cohort study achieved significance in the main end point of BDI: 11/594 without LUS vs. 0/248 with LUS $(P=0.04)$ [46]. A prospective multicenter cohort study by Machi et al. [51] reported no BDI and only three bile leaks in 1,381 patients. The study of the ability of LUS to detect BDI intraoperatively is limited to two studies in pigs in which it successfully identified wrongfully placed clips and complete transections [56, 57].

All evidence shows excellent results with LUS in delineating the biliary anatomy. The advantages of LUS over IOC are the shorter procedure time, its noninvasive nature, and lack of use of radiation. Furthermore, it may be performed prior to dissection in Calot's triangle and repeated in uncertain cases. One of the main drawbacks of LUS is the reported long learning curve. Strangely, little data about this learning curve are available. Machi et al. [51] suggested that it takes 50-100 operations before one can successfully apply LUS. Although no efficient technique should be discarded simply because it takes time to learn, this does pose a limitation for the widespread implementation of LUS.

\section{Cholecystocholangiography (CCC)}

Cholecystocholangiography (CCC) is performed by injecting radiographic contrast directly into the gallbladder. An alternative instrument for "partial" CCC is the so-called "Kumar clamp," which is placed across the base of the gallbladder, after which radiographic contrast is injected into Hartmann's pouch.

The only randomized controlled trial found a lower success rate of CCC compared to IOC (72 vs. $100 \%$, $P=0.0005)$ [58]. Also, CCC yielded inferior image quality and a 2.3 times longer radiation exposure. In comparative studies, Daoud et al. [59] reported comparable success rates for CCC and IOC, while Glattli et al. [60] found a very low success rate of $36 \%$ for CCC versus $90 \%$ in IOC. In general, success rates CCC series vary between 72 and 90\% [61-64]. CCC reduces operative time compared to IOC [58]; times necessary to perform CCC are quoted as between 2 and 14 min [59, 61, 64]. The Kumar clamp for "partial" CCC was used in only two series, with success rates of 98 and $83 \%$ [65, 66]. The above-mentioned studies are further described in Table 1.

CCC is a simple technique with a steep learning curve [61], requires no cystic duct cannulation, and is faster than IOC. However, the success rate is low $(\sim 80 \%)$, and even when successful, the image quality is often poor. Of extra concern is the report of hypotension and gallbladder perforation when the gallbladder is distended [58]. Based on these arguments, CCC is not recommended as a standard procedure for cholangiography. An exception may be partial CCC using the Kumar clamp, as this instrument allows the injection of contrast under higher pressure and needs to fill only part of the gallbladder. However, this instrument has yet to prove its superiority to standard IOC.

\section{Dye cholangiography}

It has been reported that intravenous injection of high doses of indocyanine green (ICG) in patients undergoing LC color the extrahepatic bile ducts dark blue for $2 \mathrm{~h}$ [67]. Sari et al. [68] injected methylene blue directly into the 
gallbladder and were able to identify the gallbladder, cystic duct, and CBD in 43/46 cases (93\%). Xu et al. [69] reported a success rate of $90 \%$ (18/20) (see also Table 1).

With dye cholangiography one has the advantage of being able to visualize the bile ducts prior to dissection. The technique is reasonably safe, although extravasation of the dye is not easily washed away and may obscure the view of the surgeon. The evidence for its effectiveness is limited. Xu et al. [69] indicated that the images obtained were of low resolution. None of the mentioned studies provide convincing images or quantitative data in support of the use of dye cholangiography. From a technical perspective, dyes in the visible light spectrum (380-600 nm) may not exhibit the necessary penetration necessary for a successful cholangiography, especially when Calot's triangle is filled and surrounded by fatty tissue or fibrosis resulting from a surpassed inflammatory process. This presents a serious limitation because it is in these particular cases that cholangiography has the greatest value.

\section{Light cholangiography}

Xu et al. [69] described an experimental technique called light cholangiography. An optic fiber is endoscopically passed up through the papilla of Vater and illuminates the extrahepatic duct system. Unfortunately, no images are provided, limiting the readers' ability to make a judgment on its clear merits.

Even if shown to be effective, light cholangiography done in this manner may be difficult to introduce as a routine procedure during laparoscopic cholecystectomy because it requires endoscopy with retrograde maneuvering of the optical fiber. Besides being time-consuming, this procedure is potentially hazardous, considering the reported morbidity and mortality associated with ERCP.

\section{Passive infrared cholangiography}

Liu et al. [70] experimented with a passive infrared camera. In nine pigs they infused room temperature saline or warm saline into the biliary tract, which contrasted with body temperature so that the biliary tract could be delineated (Fig. 2). Also, artificially created BDI and stones could be identified with this technique.

This method, which uses the brilliantly simple principle of small temperature differences, bypasses the ionizing radiation of IOC and can therefore take place repeatedly and in real time. However, it works only by direct infusion into the biliary system, as intravenous infusion would result in regression to body temperature within seconds. Moreover, the temperature of the saline within the bile duct may regress during the procedure necessitating repetitive

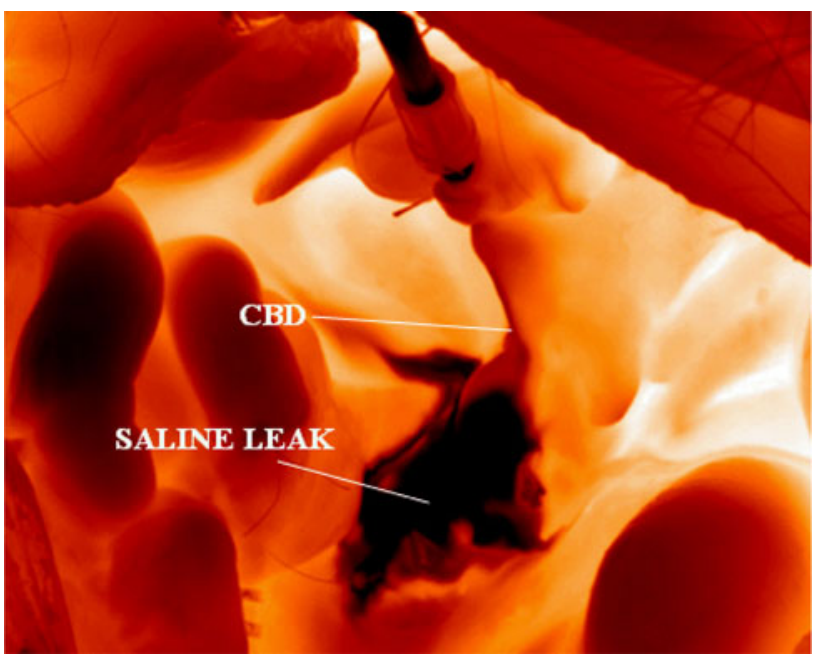

Fig. 2 Passive infrared cholangiography in a porcine model depicting leakage of room temperature saline from the common bile duct (CBD) [70] (with permission from Springer Science + Business Media, (C) 2008)

injections. Therefore, infrared cholangiography is regarded as a suboptimal technique in the operating theatre.

Near-infrared fluorescence cholangiography (NIRF-C)

In the past few years a new imaging modality has been tested for bile duct visualization: near-infrared fluorescence cholangiography (NIRF-C) [71]. This technique uses a laser to excite fluorescent agents and an imaging filter to register the light (of a slightly higher wavelength) that is subsequently emitted. Light in the NIRF spectrum $(\sim 800 \mathrm{~nm})$ has optimal penetration and minimal absorbance and scattering in human tissue. Fluorophores cleared by the liver, such as indocyanine green (ICG) and IRDye ${ }^{\circledR}$ 800CW (LI-COR Biosciences, Lincoln, NE), may be administered intravenously or directly into the biliary system for imaging purposes.

After preliminary animal studies [72], NIRF-C has been used in a small number of patients since 2008 in open and laparoscopic (Fig. 3) cholecystectomy [71, 73-76]. Fluorescent signal was detected in the bile ducts of most patients, but the images were not very clear and had limited resolution. These studies are listed in Table 1. Figueiredo et al. [77] published high-quality images of detection of BDI in a mouse model, although their relevance was limited because of the absence of periductal fat in the mouse.

Very recently, Ishizawa et al. [78] published a larger series of 52 patients in whom laparoscopic near-infrared fluorescence images of a higher resolution than in a previous series were achieved. Eight preoperatively diagnosed accessory bile ducts were also visualized by NIRF-C. 

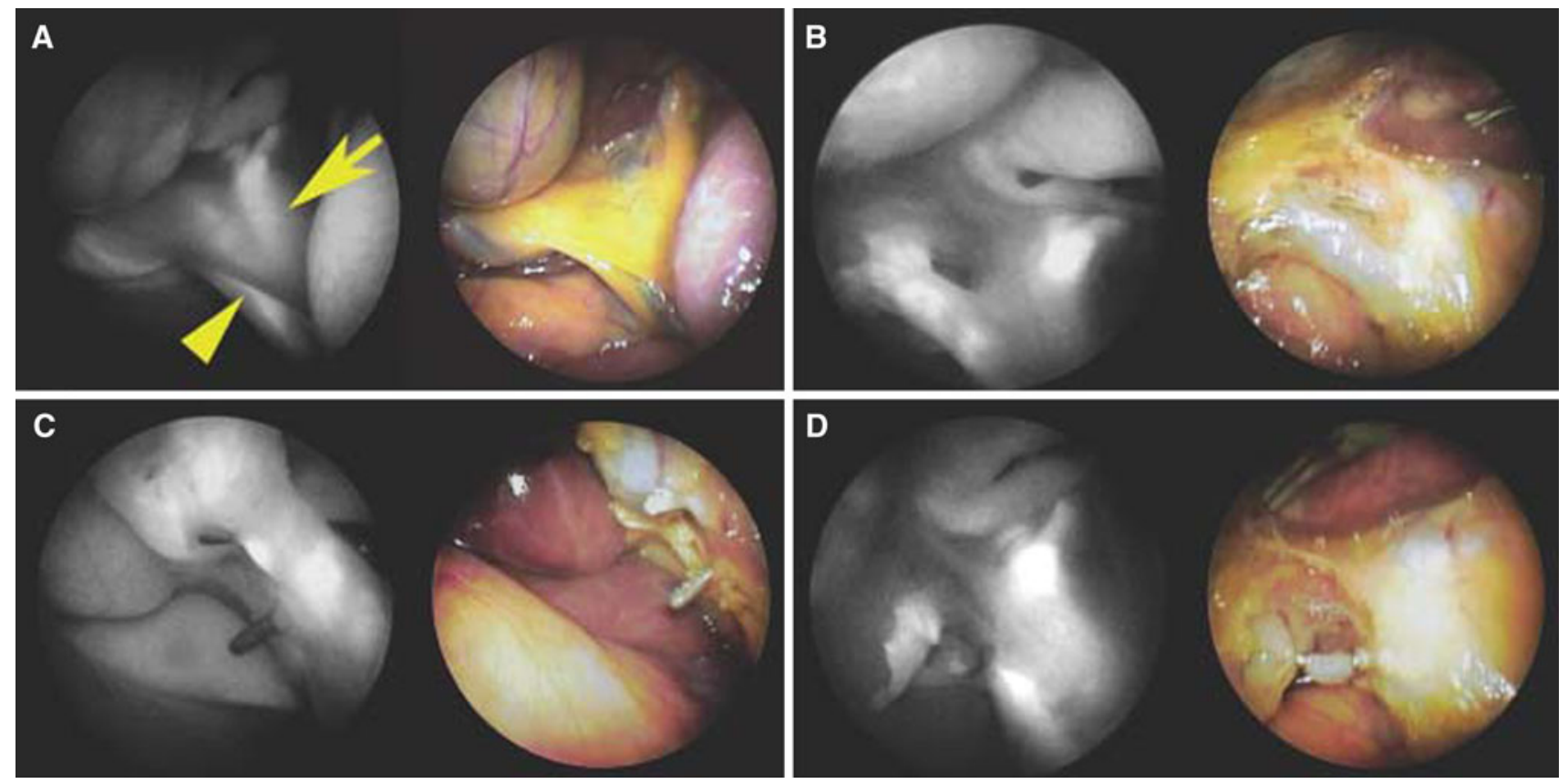

Fig. 3 Near infrared fluorescen cholangiography during laparoscopic cholecystectomy [78]. A Cystic duct running parallel to common hepatic duct, B isolation of cystic duct from anterior side of Calot's

triangle, C isolation of cystic duct from posterior side of Calot's triangle, $\mathbf{D}$ closure of cystic duct (with kind permission from John Wiley and Sons Ltd (C) 2010, all rights reserved)

Although the authors, in a letter to the editor, stated that ICG is an excellent fluorophore, novel improved fluorophores will probably further increase the quality and resolution of the images. This is necessary to decrease the potential for misinterpretation of the fluorescence images, which is vital for widespread implementation of safety measures.

A multispectral NIRF imaging system, as recently described by Themelis et al. [79], simultaneously acquires real-time color and NIRF images of the operative field. A possible drawback of fluorescence imaging is the limited penetration depth. However, penetration up to $3 \mathrm{~cm}$ through medium resembling human adipose tissue has been described [80]. This depth is sufficient to visualize structures in Calot's triangle. NIRF-C is still in its experimental stage and images acquired are not as informative as IOC. However, properly developed using high-quality cameras and bile-cleared fluorophores, NIRF-C has the potential to be a simple-to-perform, easy-to-interpret, radiation-free, and personnel-sparing bile duct visualization technique.

\section{Hyperspectral cholangiography}

Livingston et al. [81] and Zuzak et al. [82] investigated the use of hyperspectral cholangiography in pigs. This method relies on different absorption and reflection patterns of different tissue (not upon excitation and emission as in fluorescence). The authors differentiate between gallbladder tissue and vascular tissue in pigs with a sensitivity and

specificity of $98 \%$ [81]. Also, they processed the data into images that delineate the cystic duct in the hepatoduodenal ligament (Fig. 4) [82].

Hyperspectral cholangiography is appealing as it requires no exogenous contrast agent at all. Preliminary studies in pigs may be misleading as the porcine biliary system is often less obscured by fibrosis than is the human system. Validation studies in humans will need to take place before hyperspectral cholangiography may be considered a potential modality for intraoperative visualization of bile ducts.

\section{Discussion}

This article has provided an overview of the different modalities for intraoperative assessment of biliary anatomy, summarized in Table 2. The critical-view-of-safety (CVS) approach is considered the gold standard surgical technique to prevent BDI. As of yet, only a few published series were found in which achievement of CVS was specifically appraised. Although these studies suggest the protective effect of the CVS approach, future studies are necessary to appraise the effect of the CVS technique on BDI. Without an eligible alternative, and based on worldwide consensus, CVS should be regarded as the gold standard among operative techniques for assessing the biliary anatomy during laparoscopic cholecystectomy. 
Fig. 4 Hyperspectral cholangiography. A Nearinfrared (NIR) laparoscopic hyperspectral image of the hepatoduodenal ligament in live anesthetized pigs. B An artery indicated by spectra with broad oxyhemoglobin peak and a small water peak at $970 \mathrm{~nm}$. C A vein is identified by spectra containing a deoxyhemoglobin shoulder, a broad oxyhemoglobin peak, and a small water peak. D The common bile duct is associated with spectra containing a lipid shoulder and a prominent water peak [82] (with permission from Elsevier Inc., (C) 2008)
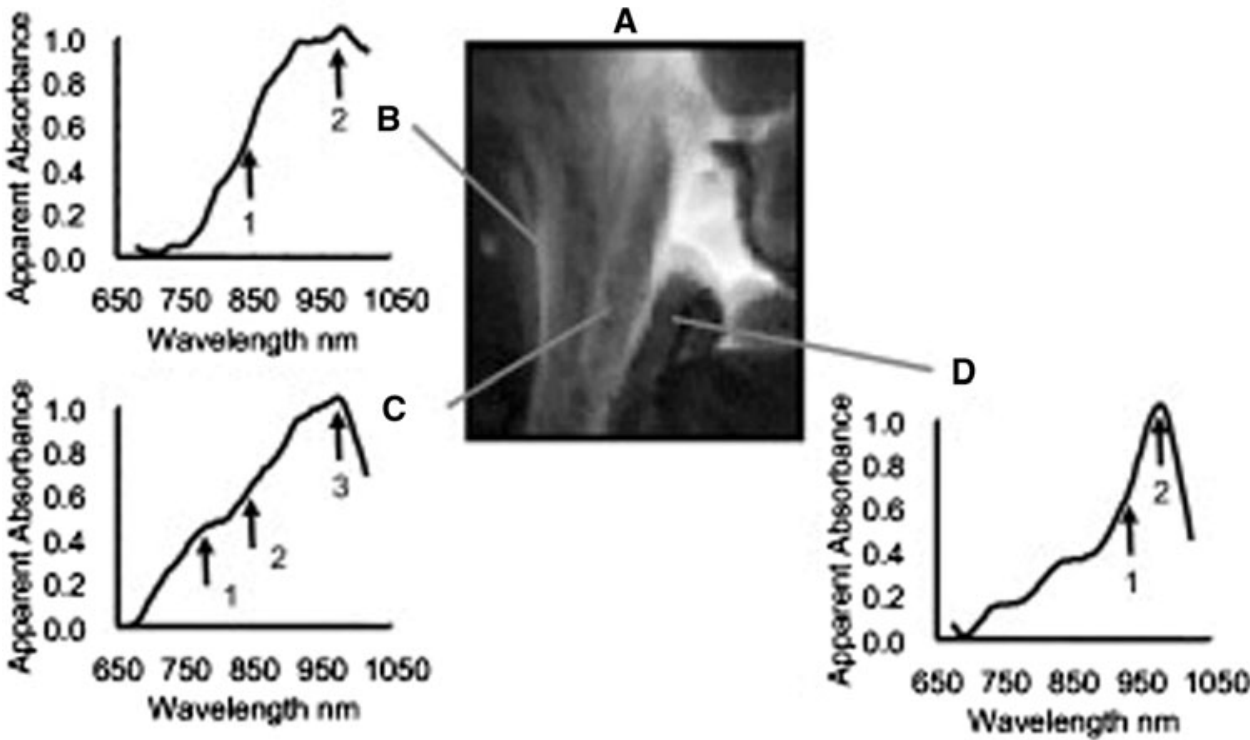

Level 1 studies on conventional IOC have not been published [83], but the consistent large-cohort studies warrant a grade B recommendation. Further research will need to show the added value of IOC as the CVS technique gains acceptance. The inherent disadvantages of IOC cannot be denied: sometimes technically challenging cystic duct cannulation, need for X-ray equipment, prolonged operation time, and additional costs. Any developments in reducing these challenges, e.g., improvement in technology for the cannulation technique, would help the general surgeon accept performing routine IOC during cholecystectomy. Also, an appropriate financial incentive to perform IOC needs to be provided by the health-care insurance system to ensure regular use of this technique.

Many "outcome" studies (level 2c evidence [83]) support laparoscopic ultrasound (LUS) for prevention of BDI. The outcome is generally excellent, thus warranting a grade $\mathrm{B}$ recommendation. It should be kept in mind that the reported studies were executed in dedicated centers with experienced surgeons. As a consequence, their results cannot be automatically extrapolated to general surgical practices worldwide. However, in trained hands, LUS is at least as effective as IOC in defining biliary anatomy, and does so in less time and radiation-free. Failure of LUS to achieve wider acceptance probably lies within the presumed long learning curve.

Cholecystocholangiography, dye cholangiography, and light cholangiography may be dismissed as valid modalities for bile duct visualization. They either have too low a success rate, yield inferior images, or are too unwieldy for routine implementation. Passive infrared cholangiography may also prove too impractical for largescale utilization.

The most promising novel developments in the field of bile duct visualization are NIRF-C and hyperspectral cholangiography. The main points to be proven in the future are whether they can provide sufficient anatomical resolution through the fatty fibrous tissue in Calot's triangle. With the development of more sensitive chargecoupled device camera systems and superior clinicalgrade NIR fluorophores, these imaging modalities may provide the ideal tool for intraoperative bile duct imaging.

This review has focused solely on bile duct visualization for prevention and early detection of BDI. A second function of bile duct visualization is the detection of CBD stones during surgery. IOC and LUS are currently the only proven modalities for this clinical purpose. Some surgeons assess for stones only if there are clinical symptoms of cholestasis or abnormal liver function tests indicative of cholestasis, in which case a routine bile duct visualization modality does not necessarily need to convey information on the presence of stones.

In summary, the search is still ongoing for an optimal technique for intraoperative assessment of biliary anatomy that is safe, easy to perform, simple to interpret, personnelsparing, cheap, and radiation-free. For now, we recommend that all surgeons use the critical-view-of-safety approach. Based on the available literature, it is recommended that intraoperative cholangiography or laparoscopic ultrasound of the biliary tree be performed routinely (grade B recommendation). In the future, hyperspectral cholangiography and near-infrared fluorescence cholangiography may prove 
Table 2 Summary of techniques and modalities for intraoperative visualization of bile ducts

\begin{tabular}{|c|c|c|c|c|c|c|}
\hline Modality & Application & Evidence & Safety & Ease & $\begin{array}{l}\text { Success } \\
\text { rate }\end{array}$ & Time \\
\hline $\begin{array}{l}\text { Critical view of safety } \\
\text { (CVS) }\end{array}$ & - & $\begin{array}{l}\text { Worldwide consensus that CVS } \\
\text { technique is the gold standard for } \\
\text { performing laparoscopic } \\
\text { cholecystectomy, but limited } \\
\text { evidence. }\end{array}$ & - & - & $90-95 \%$ & - \\
\hline $\begin{array}{l}\text { Intraoperative } \\
\text { cholangiography (IOC) }\end{array}$ & $\begin{array}{l}\text { After } \\
\text { dissection } \\
\text { in Calot's } \\
\text { triangle }\end{array}$ & $\begin{array}{l}\text { Several very large retrospective data } \\
\text { sets report association of IOC with } \\
\text { lower rates of BDI. }\end{array}$ & $\begin{array}{l}\text { Safe (minimally } \\
\text { invasive) }\end{array}$ & $\begin{array}{l}\text { At times } \\
\text { cumbersome }\end{array}$ & $90-95 \%$ & $15 \min$ \\
\hline $\begin{array}{l}\text { Laparoscopic ultrasound } \\
\text { (LUS) }\end{array}$ & Repetitively & $\begin{array}{l}\text { One retrospective study reported } \\
\text { lower rates of BDI with LUS } \\
\text { compared to no imaging modality. } \\
\text { Many prospective studies report } \\
\text { higher success rates of LUS than of } \\
\text { IOC. }\end{array}$ & $\begin{array}{l}\text { Very safe } \\
\text { (noninvasive) }\end{array}$ & $\begin{array}{l}\text { Requires } \\
\text { considerable } \\
\text { experience }\end{array}$ & $>95 \%$ & $5-10 \mathrm{~min}$ \\
\hline $\begin{array}{l}\text { Cholecystocholangiography } \\
\text { (CCC) }\end{array}$ & $\begin{array}{l}\text { Before } \\
\text { dissection } \\
\text { in Calot's } \\
\text { triangle }\end{array}$ & $\begin{array}{l}\text { One randomized controlled trial and } \\
\text { several retrospective studies all } \\
\text { show inferiority of images } \\
\text { compared to IOC. }\end{array}$ & $\begin{array}{l}\text { Reasonably safe } \\
\text { (possible added } \\
\text { risk of gallbladder } \\
\text { rupture) }\end{array}$ & Easy & $\sim 80 \%$ & $5-10 \mathrm{~min}$ \\
\hline Dye cholangiography & Real time & $\begin{array}{l}\text { Several series describe visualizing the } \\
\text { biliary tract but convincing images } \\
\text { and quantitative data are lacking. }\end{array}$ & $\begin{array}{l}\text { Reasonably safe } \\
\text { (risk of dye } \\
\text { extravasation) }\end{array}$ & Easy & $\sim 90 \%$ & $5-10 \mathrm{~min}$ \\
\hline Light cholangiography & Real time & $\begin{array}{l}\text { One series in patients is reported but } \\
\text { no images are provided. }\end{array}$ & $\begin{array}{l}\text { Potentially } \\
\text { hazardous } \\
\text { (retrograde } \\
\text { maneuvering of an } \\
\text { optical fiber into } \\
\text { CBD) }\end{array}$ & $\begin{array}{l}\text { Requires } \\
\text { endoscopy } \\
\text { skills }\end{array}$ & Unknown & Unknown \\
\hline $\begin{array}{l}\text { Passive infrared } \\
\text { cholangiography }\end{array}$ & Real time & $\begin{array}{l}\text { One study in pigs yielding excellent } \\
\text { images. }\end{array}$ & $\begin{array}{l}\text { Safe (minimally } \\
\text { invasive) }\end{array}$ & Unknown & Unknown & Unknown \\
\hline $\begin{array}{l}\text { Near-infrared fluorescence } \\
\text { cholangiography } \\
\text { (NIRF-C) }\end{array}$ & Real time & $\begin{array}{l}\text { Several animal studies yielding high- } \\
\text { quality images of the biliary tract } \\
\text { and BDI. A few small studies in } \\
\text { patients yielding images of limited } \\
\text { quality. One study of } 52 \text { patients } \\
\text { with fair results. }\end{array}$ & $\begin{array}{l}\text { Safe (noninvasive } \\
\text { when intravenous } \\
\text { agents are used) }\end{array}$ & Easy & Unknown & Unknown \\
\hline $\begin{array}{l}\text { Hyperspectral } \\
\text { cholangiography }\end{array}$ & Real time & $\begin{array}{l}\text { Two studies in pigs report positive } \\
\text { differentiation between gallbladder } \\
\text { tissue and blood vessel tissue. }\end{array}$ & $\begin{array}{l}\text { Very safe } \\
\text { (noninvasive) }\end{array}$ & Easy & Unknown & Unknown \\
\hline
\end{tabular}

$B D I$ bile duct injury, $C B D$ common bile duct

superior techniques for intraoperative visualization of the biliary anatomy.

Acknowledgments We are indebted to Dr. W. Sluiter for assistance with the statistical analysis.

Disclosures Authors K. T. Buddingh, V. B. Nieuwenhuijs, L. van Buuren, J. B. F. Hulscher, J. S. de Jong, and G. M. van Dam have no conflicts of interest or financial ties to disclose.

Open Access This article is distributed under the terms of the Creative Commons Attribution Noncommercial License which permits any noncommercial use, distribution, and reproduction in any medium, provided the original author(s) and source are credited.

\section{References}

1. Graves EJ, Owings MF (1997) 1995 summary: National Hospital Discharge Survey. Adv Data 1-10

2. Nuzzo G, Giuliante F, Giovannini I, Ardito F, D'Acapito F, Vellone M, Murazio M, Capelli G (2005) Bile duct injury during laparoscopic cholecystectomy: results of an Italian national survey on 56, 591 cholecystectomies. Arch Surg 140:986-992 
3. Bektas H, Schrem H, Winny M, Klempnauer J (2007) Surgical treatment and outcome of iatrogenic bile duct lesions after cholecystectomy and the impact of different clinical classification systems. Br J Surg 94:1119-1127

4. de Reuver PR, Rauws EA, Bruno MJ, Lameris JS, Busch OR, van Gulik TM, Gouma DJ (2007) Survival in bile duct injury patients after laparoscopic cholecystectomy: a multidisciplinary approach of gastroenterologists, radiologists, and surgeons. Surgery $142: 1-9$

5. de Reuver PR, Grossmann I, Busch OR, Obertop H, van Gulik TM, Gouma DJ (2007) Referral pattern and timing of repair are risk factors for complications after reconstructive surgery for bile duct injury. Ann Surg 245:763-770

6. Gigot J, Etienne J, Aerts R, Wibin E, Dallemagne B, Deweer F, Fortunati D, Legrand M, Vereecken L, Doumont J, Van Reepinghen P, Beguin C (1997) The dramatic reality of biliary tract injury during laparoscopic cholecystectomy. An anonymous multicenter Belgian survey of 65 patients. Surg Endosc 11: 1171-1178

7. Kern KA (1997) Malpractice litigation involving laparoscopic cholecystectomy. Cost, cause, and consequences. Arch Surg 132: 392-397

8. de Reuver PR, Sprangers MA, Rauws EA, Lameris JS, Busch OR, van Gulik TM, Gouma DJ (2008) Impact of bile duct injury after laparoscopic cholecystectomy on quality of life: a longitudinal study after multidisciplinary treatment. Endoscopy 40: 637-643

9. Alkhaffaf B, Decadt B (2010) 15 years of litigation following laparoscopic cholecystectomy in England. Ann Surg 251:682685

10. de Reuver PR, Wind J, Cremers JE, Busch OR, van Gulik TM, Gouma DJ (2008) Litigation after laparoscopic cholecystectomy: an evaluation of the Dutch arbitration system for medical malpractice. J Am Coll Surg 206:328-334

11. Way LW, Stewart L, Gantert W, Liu K, Lee CM, Whang K, Hunter JG (2003) Causes and prevention of laparoscopic bile duct injuries: analysis of 252 cases from a human factors and cognitive psychology perspective. Ann Surg 237:460-469

12. Olsen D (1997) Bile duct injuries during laparoscopic cholecystectomy. Surg Endosc 11:133-138

13. Meyers WC, Peterseim DS, Pappas TN, Schauer PR, Eubanks S, Murray E, Suhocki P (1996) Low insertion of hepatic segmental duct VII-VIII is an important cause of major biliary injury or misdiagnosis. Am J Surg 171:187-191

14. Strasberg SM, Hertl M, Soper NJ (1995) An analysis of the problem of biliary injury during laparoscopic cholecystectomy. J Am Coll Surg 180:101-125

15. Plaisier P, Pauwels M, Lange J (2001) Quality control in laparoscopic cholecystectomy: operation notes, video or photo print? HPB (Oxford) 3:197-199

16. Avgerinos C, Kelgiorgi D, Touloumis Z, Baltatzi L, Dervenis C (2009) One thousand laparoscopic cholecystectomies in a single surgical unit using the "critical view of safety" technique. J Gastrointest Surg 13:498-503

17. Yegiyants S, Collins JC (2008) Operative strategy can reduce the incidence of major bile duct injury in laparoscopic cholecystectomy. Am Surg 74:985-987

18. Sanjay P, Fulke JL, Exon DJ (2010) 'Critical view of safety' as an alternative to routine intraoperative cholangiography during laparoscopic cholecystectomy for acute biliary pathology. J Gastrointest Surg 14(8):1280-1284

19. Rawlings A, Hodgett SE, Matthews BD, Strasberg SM, Quasebarth M, Brunt LM (2010) Single-incision laparoscopic cholecystectomy: initial experience with critical view of safety dissection and routine intraoperative cholangiography. J Am Coll Surg 211:1-7
20. Yamashita Y, Kimura T, Matsumoto S (2010) A safe laparoscopic cholecystectomy depends upon the establishment of a critical view of safety. Surg Today 40:507-513

21. Strasberg SM, Brunt LM (2010) Rationale and use of the critical view of safety in laparoscopic cholecystectomy. J Am Coll Surg 211:132-138

22. Callery MP (2006) Avoiding biliary injury during laparoscopic cholecystectomy: technical considerations. Surg Endosc 20:1654 1658

23. Elakkary E, Ching K, Jacobs MJ (2006) Spiral cystic duct: beware. JSLS 10:514-516

24. Strasberg SM (2002) Avoidance of biliary injury during laparoscopic cholecystectomy. J Hepatobiliary Pancreat Surg 9:543-547

25. MacFadyen BV (2006) Intraoperative cholangiography: past, present, and future. Surg Endosc 20(Suppl 2):S436-S440

26. Stiegmann GV, Soper NJ, Filipi CJ, McIntyre RC, Callery MP, Cordova JF (1995) Laparoscopic ultrasonography as compared with static or dynamic cholangiography at laparoscopic cholecystectomy. A prospective multicenter trial. Surg Endosc 9: $1269-1273$

27. Debru E, Dawson A, Leibman S, Richardson M, Glen L, Hollinshead J, Falk GL (2005) Does routine intraoperative cholangiography prevent bile duct transection? Surg Endosc 19: 589-593

28. Videhult P, Sandblom G, Rasmussen IC (2009) How reliable is intraoperative cholangiography as a method for detecting common bile duct stones? A prospective population-based study on 1171 patients. Surg Endosc 23:304-312

29. Massarweh NN, Flum DR (2007) Role of intraoperative cholangiography in avoiding bile duct injury. J Am Coll Surg 204: 656-664

30. Hobbs MS, Mai Q, Knuiman MW, Fletcher DR, Ridout SC (2006) Surgeon experience and trends in intraoperative complications in laparoscopic cholecystectomy. Br J Surg 93:844853

31. Flum DR, Dellinger EP, Cheadle A, Chan L, Koepsell T (2003) Intraoperative cholangiography and risk of common bile duct injury during cholecystectomy. JAMA 289:1639-1644

32. Flum DR, Koepsell T, Heagerty P, Sinanan M, Dellinger EP (2001) Common bile duct injury during laparoscopic cholecystectomy and the use of intraoperative cholangiography: adverse outcome or preventable error? Arch Surg 136:1287-1292

33. Waage A, Nilsson M (2006) Iatrogenic bile duct injury: a population-based study of 152,776 cholecystectomies in the Swedish Inpatient Registry. Arch Surg 141:1207-1213

34. Z'graggen K, Wehrli H, Metzger A, Buehler M, Frei E, Klaiber C (1998) Complications of laparoscopic cholecystectomy in Switzerland. A prospective 3-year study of 10, 174 patients. Swiss Association of Laparoscopic and Thoracoscopic Surgery. Surg Endosc 12:1303-1310

35. Giger U, Ouaissi M, Schmitz SF, Krahenbuhl S, Krahenbuhl L (2011) Bile duct injury and use of cholangiography during laparoscopic cholecystectomy. Br J Surg 98(3):391-396

36. Metcalfe MS, Ong T, Bruening MH, Iswariah H, WemyssHolden SA, Maddern GJ (2004) Is laparoscopic intraoperative cholangiogram a matter of routine? Am J Surg 187:475-481

37. Talamini MA (2003) Routine vs selective intraoperative cholangiography during cholecystectomy. JAMA 289:1691-1692

38. El Shallaly G, Seow C, Sharp C, Mughrabi A, Nassar AH (2005) Intraoperative cholangiography time in laparoscopic cholecystectomy: timing the radiographer. Surg Endosc 19: 1370-1372

39. Khaira HS, Ridings PC, Gompertz RH (1999) Routine laparoscopic cholangiography: a means of avoiding unnecessary endoscopic retrograde cholangiopancreatography. J Laparoendosc Adv SurgTech A 9:17-22 
40. Piacentini F, Perri S, Pietrangeli F, Nardi M Jr, Dalla Torre A, Nicita A, Lotti R, Castaldo P, Gabbrielli F, Castiglia D, Citone G (2003) Intraoperative cholangiography during laparoscopic cholecystectomy: selective or routine? G Chir 24:123-128

41. Karthikesalingam A, Markar SR, Weerakkody R, Walsh SR, Carroll N, Praseedom RK (2009) Radiation exposure during laparoscopic cholecystectomy with routine intraoperative cholangiography. Surg Endosc 23:1845-1848

42. Molloy M, Bower RH, Hasselgren PO, Dalton BJ (1999) Cholangiography during laparoscopic cholecystectomy-cumulative sum analysis of an institutional learning curve. J Gastrointest Surg 3:185-188

43. Flum DR, Flowers C, Veenstra DL (2003) A cost-effectiveness analysis of intraoperative cholangiography in the prevention of bile duct injury during laparoscopic cholecystectomy. J Am Coll Surg 196:385-393

44. Machi J, Tateishi T, Oishi AJ, Furumoto NL, Oishi RH, Uchida S, Sigel B (1999) Laparoscopic ultrasonography versus operative cholangiography during laparoscopic cholecystectomy: review of the literature and a comparison with open intraoperative ultrasonography. J Am Coll Surg 188:360-367

45. Catheline J, Rizk N, Champault G (1999) A comparison of laparoscopic ultrasound versus cholangiography in the evaluation of the biliary tree during laparoscopic cholecystectomy. Eur J Ultrasound 10:1-9

46. Biffl WL, Moore EE, Offner PJ, Franciose RJ, Burch JM (2001) Routine intraoperative laparoscopic ultrasonography with selective cholangiography reduces bile duct complications during laparoscopic cholecystectomy. J Am Coll Surg 193: 272-280

47. Catheline JM, Turner R, Paries J (2002) Laparoscopic ultrasonography is a complement to cholangiography for the detection of choledocholithiasis at laparoscopic cholecystectomy. Br J Surg 89:1235-1239

48. Hakamada K, Narumi S, Toyoki Y, Nara M, Oohashi M, Miura T, Jin H, Yoshihara S, Sugai M, Sasaki M (2008) Intraoperative ultrasound as an educational guide for laparoscopic biliary surgery. World J Gastroenterol 14:2370-2376

49. Kimura T, Umehara Y, Yoshida M, Sakuramachi S, Kawabe A, Suzuki K (1999) Laparoscopic ultrasonography and operative cholangiography prevent residual common bile duct stones in laparoscopic cholecystectomy. Surg Laparosc Endosc Percutan Tech 9:124-128

50. Machi J, Oishi AJ, Tajiri T, Murayama KM, Furumoto NL, Oishi RH (2007) Routine laparoscopic ultrasound can significantly reduce the need for selective intraoperative cholangiography during cholecystectomy. Surg Endosc 21:270-274

51. Machi J, Johnson JO, Deziel DJ, Soper NJ, Berber E, Siperstein A, Hata M, Patel A, Singh K, Arregui ME (2009) The routine use of laparoscopic ultrasound decreases bile duct injury: a multicenter study. Surg Endosc 23:384-388

52. Onders RP, Hallowell PT (2005) The era of ultrasonography during laparoscopic cholecystectomy. Am J Surg 189:348-351

53. Perry KA, Myers JA, Deziel DJ (2008) Laparoscopic ultrasound as the primary method for bile duct imaging during cholecystectomy. Surg Endosc 22:208-213

54. Tranter SE, Thompson MH (2001) Potential of laparoscopic ultrasonography as an alternative to operative cholangiography in the detection of bile duct stones. Br J Surg 88:65-69

55. Tranter SE, Thompson MH (2003) A prospective single-blinded controlled study comparing laparoscopic ultrasound of the common bile duct with operative cholangiography. Surg Endosc 17:216-219

56. Birth M, Carroll BJ, Delinikolas K, Eichler M, Weiser H (1996) Recognition of laparoscopic bile duct injuries by intraoperative ultrasonography. Surg Endosc 10:794-797
57. Birth M, Roblick U, Brugmans F, Weiser HF, Bruch HP (1999) Laparoscopic ultrasonography reliably visualizes bile-duct injuries-a blind randomized porcine study. Langenbecks Arch Surg 384:360-365

58. Wills VL, Jorgensen JO, Hunt DR (2000) A randomized controlled trial comparing cholecystocholangiography with cystic duct cholangiography during laparoscopic cholecystectomy. Aust N Z J Surg 70:573-577

59. Daoud M, McCallum MJ (1999) An easy and effective method of cholangiography in laparoscopic cholecystectomy: laparoscopic cholecystocholangiography. Aust N Z J Surg 69:138-140

60. Glattli A, Metzger A, Klaiber C, Seiler C, Maddern GJ, Baer HU (1994) Cholecystocholangiography vs cystic duct cholangiography during laparoscopic cholecystectomy. A prospective controlled trial. Surg Endosc 8:299-301

61. Fox AD, Baigrie RJ, Cobb RA, Dowling BL (1996) Peroperative cholangiography through the gallbladder (cholecystocholangiography) during laparoscopic cholecystectomy. Surg Laparosc Endosc 6:22-25

62. Koksal E (2001) Cholecystocholangiography during laparoscopic cholecystectomy. Surg Today 31:877-880

63. Moont M (1995) Cholecystocholangiography. Surg Endosc 9:544-546

64. Young C, Moont M (1998) Routine cholecystocholangiography: a viable alternative during laparoscopic cholecystectomy. Aust $\mathrm{N}$ Z J Surg 68:425-427

65. Holzman MD, Sharp K, Holcomb GW, Frexes-Steed M, Richards WO (1994) An alternative technique for laparoscopic cholangiography. Surg Endosc 8:927-930

66. Kumar SS (1992) Laparoscopic cholangiography: a new method and device. J Laparoendosc Surg 2:247-254

67. Pertsemlidis D (2009) Fluorescent indocyanine green for imaging of bile ducts during laparoscopic cholecystectomy. Arch Surg 144:978

68. Sari YS, Tunali V, Tomaoglu K, Karagoz B, Guneyi A, Karagoz I (2005) Can bile duct injuries be prevented? "A new technique in laparoscopic cholecystectomy”. BMC Surg 5:14

69. Xu F, Xu CG, Xu DZ (2004) A new method of preventing bile duct injury in laparoscopic cholecystectomy. World J Gastroenterol 10:2916-2918

70. Liu JJ, Alemozaffar M, McHone B, Dhanani N, Gage F, Pinto PA, Gorbach AM, Elster E (2008) Evaluation of real-time infrared intraoperative cholangiography in a porcine model. Surg Endosc 22:2659-2664

71. Ishizawa $\mathrm{T}$, Tamura $\mathrm{S}$, Masuda $\mathrm{K}$, Aoki $\mathrm{T}$, Hasegawa $\mathrm{K}$, Imamura H, Beck Y, Kokudo N (2009) Intraoperative fluorescent cholangiography using indocyanine green: a biliary road map for safe surgery. J Am Coll Surg 208:e1-e4

72. Tanaka E, Choi HS, Humblet V, Ohnishi S, Laurence RG, Frangioni JV (2008) Real-time intraoperative assessment of the extrahepatic bile ducts in rats and pigs using invisible nearinfrared fluorescent light. Surgery 144:39-48

73. Mitsuhashi N, Kimura F, Shimizu H, Imamaki M, Yoshidome H, Ohtsuka M, Kato A, Yoshitomi H, Nozawa S, Furukawa K, Takeuchi D, Takayashiki T, Suda K, Igarashi T, Miyazaki M (2008) Usefulness of intraoperative fluorescence imaging to evaluate local anatomy in hepatobiliary surgery. J Hepatobiliary Pancreat Surg 15:508-514

74. Ishizawa T, Bandai Y, Kokudo N (2009) Fluorescent cholangiography using indocyanine green for laparoscopic cholecystectomy: an initial experience. Arch Surg 144:381-382

75. Aoki T, Murakami M, Yasuda D, Shimizu Y, Kusano T, Matsuda $\mathrm{K}$, Niiya T, Kato H, Murai N, Otsuka K, Kusano M, Kato T (2010) Intraoperative fluorescent imaging using indocyanine green for liver mapping and cholangiography. J Hepatobiliary Pancreat Surg 17(5):590-594 
76. Tagaya N, Shimoda M, Kato M, Nakagawa A, Abe A, Iwasaki Y, Oishi H, Shirotani N, Kubota K (2010) Intraoperative exploration of biliary anatomy using fluorescence imaging of indocyanine green in experimental and clinical cholecystectomies. J Hepatobiliary Pancreat Surg 17(5):595-600

77. Figueiredo JL, Siegel C, Nahrendorf M, Weissleder R (2010) Intraoperative near-infrared fluorescent cholangiography (NIRFC) in mouse models of bile duct injury. World J Surg 34:336-343

78. Ito K, Ito H, Whang EE (2008) Timing of cholecystectomy for biliary pancreatitis: do the data support current guidelines? J Gastrointest Surg 12:2164-2170

79. Themelis G, Yoo JS, Soh KS, Schulz R, Ntziachristos V (2009) Real-time intraoperative fluorescence imaging system using lightabsorption correction. J Biomed Opt 14:064012

80. Houston JP, Thompson AB, Gurfinkel M, Sevick-Muraca EM (2003) Sensitivity and depth penetration of continuous wave versus frequency-domain photon migration near-infrared fluorescence contrast-enhanced imaging. Photochem Photobiol 77: $420-430$

81. Livingston EH, Gulaka P, Kommera S, Wang B, Liu H (2009) In vivo spectroscopic characterization of porcine biliary tract tissues: first step in the development of new biliary tract imaging devices. Ann Biomed Eng 37:201-209
82. Zuzak KJ, Naik SC, Alexandrakis G, Hawkins D, Behbehani K, Livingston E (2008) Intraoperative bile duct visualization using near-infrared hyperspectral video imaging. Am J Surg 195: 491-497

83. Phillips B, Ball C, Sacket D, Badenoch D, Straus S, Haynes B, Dawes M (2009) Oxford Centre for evidence-based medicine, levels of evidence and grades of recommendation. Available at www.cebm.net/?o=1025. Accessed January 2010

84. Fletcher DR, Hobbs MS, Tan P, Valinsky LJ, Hockey RL, Pikora TJ, Knuiman MW, Sheiner HJ, Edis A (1999) Complications of cholecystectomy: risks of the laparoscopic approach and protective effects of operative cholangiography: a population-based study. Ann Surg 229:449-457

85. Krahenbuhl L, Sclabas G, Wente MN, Schafer M, Schlumpf R, Buchler MW (2001) Incidence, risk factors, and prevention of biliary tract injuries during laparoscopic cholecystectomy in Switzerland. World J Surg 25:1325-1330

86. Ishizawa T, Bandai Y, Ijichi M, Kaneko J, Hasegawa K, Kokudo N (2010) Fluorescent cholangiography illuminating the biliary tree during laparoscopic cholecystectomy. Br J Surg 97(9): 1369-1377 